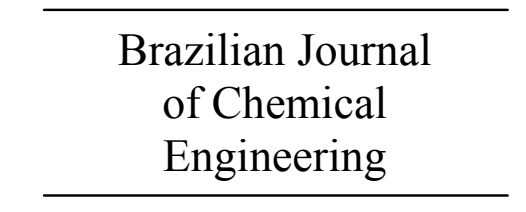

ISSN 0104-6632

Printed in Brazil

www.abeq.org.br/bjche

Vol. 30, No. 03, pp. 667 - 676, July - September, 2013

\title{
EFFECT OF DRYING CONDITIONS ON THE PHYSICAL PROPERTIES OF IMPREGNATED ORANGE PEEL
}

\author{
K. Manjarres-Pinzon ${ }^{1}$, M. Cortes-Rodriguez ${ }^{2}$ and E. Rodríguez-Sandoval ${ }^{2 *}$ \\ ${ }^{1}$ Department of Food Engineering, Faculty of Engineering, Universidad del Valle, Cali, Valle del Cauca, Colombia. \\ E-mail: katherine.manjarres@gmail.com \\ ${ }^{2}$ Department of Agricultural and Food Engineering, Faculty of Agricultural Science, Phone: + 57-4-4309065, Fax: + 57-4-4309014, \\ Cll 59 No. 63-02, B14, Of 303, Núcleo el Volador, Universidad Nacional de Colombia, Medellín, Antioquia, Colombia. \\ E-mail: edrodriguezs@unal.edu.co
}

(Submitted: June 11, 2012 ; Revised: October 21, 2012 ; Accepted: October 31, 2012)

\begin{abstract}
Orange peel represents approximately 30-40 g/100g of the fresh fruit weight and could be used to develop value-added products. Hence, this study aims to evaluate the effects of drying conditions on the physical properties of orange peel impregnated with sucrose solution. The response surface method (RSM) was used to optimize two parameters: drying temperature $\left(35-55{ }^{\circ} \mathrm{C}\right)$ and air flow rate $(2-3 \mathrm{~m} / \mathrm{s})$. The measured responses used to determine the effect of dying process conditions were: moisture content. drying time. total soluble solids. color and hardness. The dried orange peels from the optimal process were subjected to a sensory test by 60 consumers. The optimum conditions for the drying of orange peels were determined to obtain minimum hardness, moisture content and drying time for $\mathrm{a}_{\mathrm{w}}$ values below 0.6 . The optimum conditions were found to be a dying temperature of $52.3{ }^{\circ} \mathrm{C}$ and air flow rate of $2.0 \mathrm{~m} / \mathrm{s}$. At this point, drying time, hardness and moisture content were found to be $20 \mathrm{~h}, 78.4 \mathrm{~N}$ and $7.6 \%$, respectively. The sensory results showed that consumers aged over 30 years old accepted well the dried orange peel.

Keywords: Dried peel; Orange; Impregnation; Drying conditions.
\end{abstract}

\section{INTRODUCTION}

There is a considerable emphasis on the recovery, recycling and upgrading of wastes. This is particularly valid for the food and food processing industry, in which wastes, effluents, residues, and by-products can be recovered and can often be upgraded to useful higher value products. The food industry produces large volumes of wastes, both solids and liquids, resulting from the production, preparation, and consumption of food. Food processing wastes might have a potential for recycling raw materials, for conversion into useful byproducts of higher value, or even raw materials for other industries, or for use as food or feed
(Laufenberg et al., 2003; Brião and Granhen Tavares, 2007).

The food industry has shown a special interest in finding uses for citrus industry by-products. During the citrus juice extraction process, thousands of tons of by-products are produced (Garau et al., 2007). In this sense, orange peel could be dehydrated for different products such as powders, flakes and slices (Ruiz-Díaz et al., 2003). The development of new processing methods that preserve the quality of peels and improve their sensory acceptance is required to produce new peel foods. Vacuum impregnation (VI) with adequate solutions combined with air drying can be an interesting technique in order to develop high quality peel products like food ingredients or as

*To whom correspondence should be addressed 
a raw material for secondary processes (Chafer et al., 2003).

Drying has become a widely used way of food processing, allowing the extension of the shelf-life of fruits and vegetables. However, processing may cause irreversible modifications to the cell wall polysaccharides, affecting their original structure (Femenia et al., 2009). Therefore, the final quality of the dried by-products can be determined by structural and compositional modifications which might occur during the pretreatment and drying process (Garau et al., 2007). In previous studies into citrus peel dehydration, the influence of drying conditions and the equipment applied in the process were assessed. The effect of air drying temperature on the functional properties of dietary fiber obtained from orange by-products was evaluated (Garau et al., 2007). The application of high-intensity ultrasound, high speed drying, and solar drying on the drying kinetics of orange peel and its antioxidant activity have been assessed (Garcia-Perez et al., 2012; Senevirathne et al., 2009; Slama and Combarnous, 2011). The increase in pectin yield was investigated as a result of microwave heating of fresh orange peels (Kratchanova et al., 2004).

The aim of this study was to assess the effects of drying temperature and air flow rate on the physical properties of orange peel impregnated with sucrose solution in order to find the best drying conditions. The response surface method (RSM) was used to optimize the hot air drying process considering the effects of these variables and their interactions on drying time and quality evaluation of dried orange peels.

\section{MATERIALS AND METHODS}

\section{Sample Preparation}

Fresh oranges (Citrus sinensis var. Valencia) obtained from a local market were washed with tap water, cut in half and, after the juice extraction, the peel and the remaining pulp were separated. The bitter taste of orange peel is due to the presence of hesperidin and naringin. These flavonoids are watersoluble at $83{ }^{\circ} \mathrm{C}$ (melting point) in a basic solution. The orange peel was soaked in sodium bicarbonate $\left(\mathrm{NaHCO}_{3}\right)$ solution at $2 \mathrm{~g} / 100 \mathrm{~g}$ for $20 \mathrm{~min}$ at boiling temperature $\left(95^{\circ} \mathrm{C}\right)$ as the debittering method. The samples was cooled and cut into triangles (height $90 \pm 1.5 \mathrm{~mm}$ and thickness $5 \pm 1.8 \mathrm{~mm}$ ). At this stage of the process, the moisture content of samples was in the range of $60-80 \mathrm{~g} / 100 \mathrm{~g}$. Then, the peel orange samples were impregnated with a $45^{\circ}$ Brix sucrose solution by applying vacuum (20 in of $\mathrm{Hg}$ ) for $5 \mathrm{~min}$ using an impregnation system (Centricol Ltda, Medellin, Colombia) and then restoring atmospheric pressure, keeping the samples immersed for $10 \mathrm{~min}$ more (Contreras et al., 2005).

\section{Drying Experiments}

The drying experiments were conducted in a laboratory scale hot air oven (Centricol Ltda, Medellin, Colombia) equipped with automatic temperature and air flow rate control devices, an electronic balance and an integrated data acquisition system. Samples (250 g) were placed on two steel shelves per treatment. Drying was performed until the water activity $\left(a_{w}\right)$ of the samples was less than 0.6 because, below this $a_{w}$ the microbiological spoilage of dried samples could be prevented (Ramaswamy and Marcotte, 2006). Samples were placed in the dryer to measure water activity without changing the weights recorded in the trays. The measured water activity was close to 0.6 .

Drying temperatures from $35^{\circ} \mathrm{C}$ to $55^{\circ} \mathrm{C}$ and air flow rates between $2 \mathrm{~m} / \mathrm{s}$ to $3 \mathrm{~m} / \mathrm{s}$ were assessed in the process (Atarés et al., 2009). The weight loss of the sample was recorded during the process by a data acquisition system, which was connected to the dryer tray. The registered weights were expressed in terms of free moisture contents ( $\mathrm{kg}$ water $/ \mathrm{kg}$ dry matter) (Geankoplis 1993; Barajas et al., 2012). Then, the drying kinetics curves were determined as a function of moisture ratio (Equation 1) and the time to dry the samples to the desired water activity was obtained.

$M R=\frac{X(t)-X_{e}}{X_{0}-X_{e}}$

where $\mathrm{X}_{\mathrm{e}}, \mathrm{X}_{0}, \mathrm{X}(\mathrm{t})$ are the equilibrium moisture content, the initial moisture content, and the moisture content at any time ( $\mathrm{kg}$ water $/ \mathrm{kg}$ dry matter), respectively, and MR is the moisture ratio.

\section{Methods}

The moisture content of samples was obtained according to the AOAC method 20.013 (AOAC. $1980)$. The water activity $\left(a_{w}\right)$ of samples was determined with a dew point hygrometer at $25{ }^{\circ} \mathrm{C}$ (Aqualab series 3TE. Decagon Devices Inc., Pullman, WA, USA) (El-Aouar et al., 2006). Measurements were made in triplicate. The color of the surface of samples was measured using a sphere 
spectrocolorimeter (Model SP60, X-Rite Inc., MI, USA) with the illuminant D65 and an observer of $10^{\circ}$ as a reference. The measurement was performed with the included specular component. The color values were expressed in the CIELab space as $\mathbf{L}$ (lightness, from 0 black to 100 white), a (green chromaticity (-) to red $(+)$ ), and b (blue chromaticity (-) to yellow (+)) (Claussen et al., 2007). Total soluble solids (TSS) were determined according to the method of AOAC 932.12 (AOAC. 1980). Dried samples (5 g) were rehydrated in distilled water $(50 \mathrm{~g})$ for $1 \mathrm{~h}$ and ground using an Ultra Turrax homogenizer (45 S5, IKA-Werke, Staufen, Germany). The mixture was filtered through Whatman \#1 paper and TSS were measured as ${ }^{\circ}$ Brix using a refractometer at $20{ }^{\circ} \mathrm{C}$. The hardness of the dried orange peel samples was measured using a texture analyzer (TA-XT2i, Stable Micro System, Surrey, UK) equipped with a $50 \mathrm{~kg}$ load cell and the software Texture Expert Exceed v. 2.64 (Kotwaliwale et al., 2007). The test was performed using a cylindrical probe $(\mathrm{P} / 2)(2 \mathrm{~mm}$ diameter) with a pre-test speed of $2 \mathrm{~mm} / \mathrm{s}$ and a test speed of $2 \mathrm{~mm} / \mathrm{s}$. At least 10 units of samples were used in these tests for each treatment.

The sensory evaluation was an affective test in order to assess the personal response (preference and/or acceptance) by potential customers of a dried product. This test was made using the dried orange peels from the optimized drying condition, which were coated with chocolate. A group of 60 customers of fresh orange fruit between 20-60 years old was chosen from the Universidad Nacional de Colombia campus Medellin. The customers understood the test procedure and responded to it but they did not know why the study was performed. The data were registered by recording the number of persons who accepted or rejected the samples. The table for estimating the significance of the difference showed whether the acceptance was significant or not (1-tail, paired t-test, $\mathrm{P}<0.05$ ) (Meilgaard et al., 1999).

\section{Statistical Analysis}

The experimental design was based on a range of the process parameters that was determined in the preliminary investigations to include the optimum. Response surface methodology (RSM) and 2-factor central-composite design were applied to assess the drying temperature $\left(35-55^{\circ} \mathrm{C}\right)$ and the air flow rate $(2-3 \mathrm{~m} / \mathrm{s})$. There were five replicates at the center point and a single run for each of the other combinations; a total of thirteen experiments were carried out. The coded and uncoded values of the two independent variables are shown in Table 1. The moisture content, total soluble solids, hardness, color and drying time were considered as dependent variables to assess the effect of drying temperature and air flow rate on the dried orange peel. ANOVA was used at the 0.05 significance level. Statistical analysis was performed using Design Expert 8.0.5.2 (Stat-Ease Inc., Minneapolis, MT). Experimental data were fitted to linear, cross-product and second order polynomial models for drying time, moisture content and hardness as a function of drying temperature and air flow rate. Mathematical models were evaluated for each response by means of multiple regression analysis. The model adequacies were checking by fitted $\mathrm{R}^{2}$, sum of squares of model, residual, pure error, lack of fit, and coefficient of variation (CV) (Myers and Montgomery, 2002).

Table 1: Experimental design for the drying process of orange peel samples in coded and uncoded values.

\begin{tabular}{|c|c|c|c|c|}
\hline \multirow{2}{*}{ Run order } & \multicolumn{2}{|c|}{ Coded values } & \multicolumn{2}{c|}{ Uncoded values } \\
\cline { 2 - 5 } & Drying temperature (X1) & Air flow rate (X2) & Drying temperature $\left(\mathbf{~}^{\mathbf{0}} \mathbf{C}\right)$ & Air flow rate (m/s) \\
\hline 1 & 1.414 & 0 & 60 & 2.50 \\
2 & 0 & 0 & 45 & 2.50 \\
3 & 0 & 0 & 45 & 2.50 \\
4 & 1 & -1 & 55 & 2.00 \\
5 & 1 & 1 & 55 & 3.00 \\
6 & -1.414 & 0 & 30 & 2.50 \\
7 & 0 & 0 & 45 & 2.50 \\
8 & -1 & 1 & 35 & 3.00 \\
9 & 0 & 0 & 45 & 2.50 \\
10 & 0 & -1.414 & 45 & 1.75 \\
11 & -1 & -1 & 35 & 2.00 \\
12 & 0 & 0 & 45 & 2.50 \\
13 & 0 & 1.414 & 45 & 3.25 \\
\hline
\end{tabular}


During the optimization of processes, several response variables describing the quality characteristics and performance of the systems are usually optimized. Some of these variables are to be maximized while some are to be minimized. In many cases, these responses are competing, i.e., improving one response may have an opposite effect on another one, which further complicates the situation. One approach to optimization was to solve the problem of multiple responses through the use of a desirability function combining all responses into one measurement (Erbay and Icier, 2009). Some steps of developing desirability functions for optimization include to making the response variables dimensionless, to decide the weighting coefficient, to constitute the desirability function and solution, and to perform the optimization by fuzzy or similar predictable ratio method (Shi et al., 2008).

\section{RESULTS AND DISCUSSION}

\section{Drying Curves}

The orange peel drying kinetics curves are shown in Figure 1. The drying curves were similar to those obtained for peels from different citrus fruits (Garau et al., 2007; Garcia-Perez et al., 2009; Ortuño et al., 2010). Air drying temperature had an important influence on the drying rate. The drying temperature affected significantly $(\mathrm{P}<0.05)$ the drying time of samples, but this response was not affected significantly by air flow rate (Figure 2(a)). Higher drying temperature promoted shorter drying times, whereas longer drying periods were required at lower drying temperatures (Garau et al., 2007; Barajas et al., 2012). For instance, $45 \mathrm{~h}$ was required to reach a water activity lower than 0.6 at $30{ }^{\circ} \mathrm{C}$, whereas the same water activity could be reached in $7 \mathrm{~h}$ with an air drying temperature of $60{ }^{\circ} \mathrm{C}$. The drying time at $45{ }^{\circ} \mathrm{C}$ (the central point) was in the range of 20-25 h.

García-Perez et al. (2009) and Ortuño et al. (2010) studied the influence of applied acoustic energy on the convective drying kinetics at $40{ }^{\circ} \mathrm{C}$ assisted by power ultrasound of lemon and orange peels and reported drying times between 3 and $7 \mathrm{~h}$ according to the applied acoustic power density. Wuttipalakorn et al. (2009) showed drying times of lime peels undergoing hot air drying at $80{ }^{\circ} \mathrm{C}$ between 4 and $6 \mathrm{~h}$, depending on the ethanol concentration of the pretreatment solution used to reduce the initial moisture content of the samples. Garau et al. (2007) assessed the convective drying kinetics of dried orange peels between 30 and $90{ }^{\circ} \mathrm{C}$ and established drying times of $8.3 \mathrm{~h}$ at $30^{\circ} \mathrm{C}$ and $2.5 \mathrm{~h}$ at $60{ }^{\circ} \mathrm{C}$. On the other hand, Miller and Braddock (1982) reported a 40 min drying time for citrus peel $(100 \mathrm{~g})$ subjected to microwave heating (1.5 kW). Slama and Combarnous (2011) determined drying kinetics of orange peel in a solar dryer with a controlled procedure for temperature, pressure, air flow and moisture of drying, and reported a drying time of $3.3 \mathrm{~h}$ for air flow rates varying from 1.24 to $2.1 \mathrm{~m} / \mathrm{s}$ at $75{ }^{\circ} \mathrm{C}$. The drying times of citrus peels change due to the drying systems and conditions, pretreatments, sample size and the equilibrium moisture contents reached in the process, as described above.

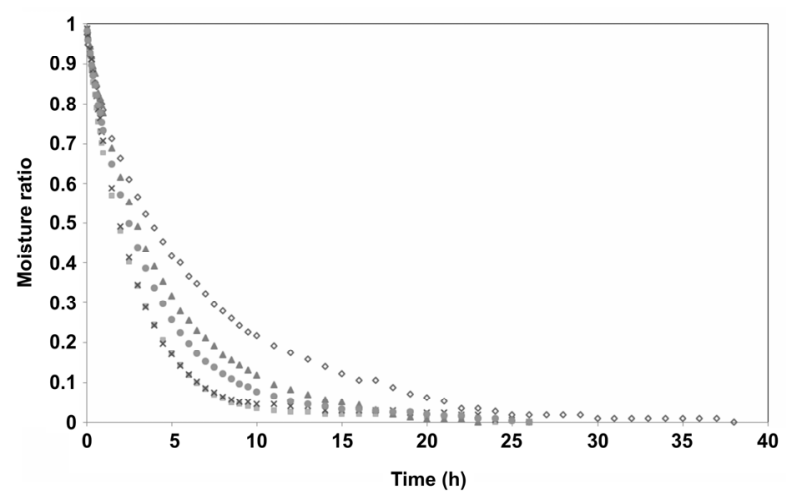

(a)

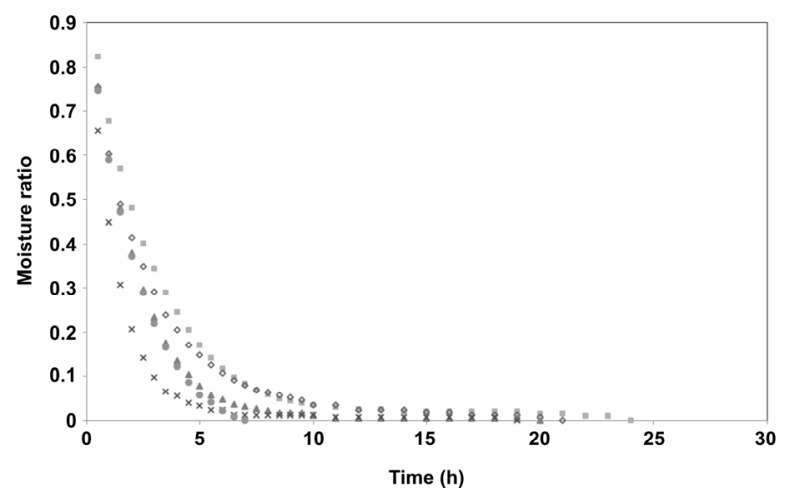

(b)

Figure 1: Drying curves of orange peel from $30^{\circ} \mathrm{C}$ to $45^{\circ} \mathrm{C}$ (a) and from $45^{\circ} \mathrm{C}$ to $60^{\circ} \mathrm{C}$ (b); $45^{\circ} \mathrm{C}$ and $2.5 \mathrm{~m} / \mathrm{s}(\mathbf{\bullet}) ; 30{ }^{\circ} \mathrm{C}$ and $2.5 \mathrm{~m} / \mathrm{s}(\diamond) ; 45^{\circ} \mathrm{C}$ and 3.25 $\mathrm{m} / \mathrm{s}(\diamond) ; 35{ }^{\circ} \mathrm{C}$ and $2.0 \mathrm{~m} / \mathrm{s}(\boldsymbol{\Delta}) ; 55^{\circ} \mathrm{C}$ and $2.0 \mathrm{~m} / \mathrm{s}$ (४); $35^{\circ} \mathrm{C}$ and $3 \mathrm{~m} / \mathrm{s}(\times) ; 55^{\circ} \mathrm{C}$ and $3 \mathrm{~m} / \mathrm{s}(\times) ; 45^{\circ} \mathrm{C}$ and $1.75 \mathrm{~m} / \mathrm{s}(\bullet) ; 60^{\circ} \mathrm{C}$ and $2.5 \mathrm{~m} / \mathrm{s}(\bullet)$.

The vacuum impregation (VI) process of orange peel occurs in the tissue zone of albedo (fleshy middle layer of the pericarp of citrus fruit), whereas the flavedo cells (outermost layer of the pericarp) are 
not affected by VI. Citrus peels are very porous, especially the albedo zone, which is composed of several non-turgid cells (enlarged to a greater or lesser degree) with wide intercellular spaces (Chafer et al., 2003). This particular cell arrangement of albedo has the ability to swell in line with both the out flow of internal gas (during the vacuum step) and the impregnation of the pores with external liquid. The great amount of water-soluble and compatible polysaccharides in the extracellular volume contributes to the retention of a great amount of impregnated water (from the external solution). These changes in the albedo structure after VI operations contribute to the retention of water during the drying process. For that reason, the drying times of impregnated citrus peels were long compared to other studies.

\section{Physical Properties}

Dehydrated foods are preserved because $\mathrm{a}_{\mathrm{w}}$ is at a level where no microbiological activity can occur and where deteriorative chemical and biochemical reaction rates are reduced to a minimum (Toledo, 2007). Reducing $a_{w}$ below 0.6 prevents microbiological spoilage; however, other deteriorative reactions, such as enzymatic activity, non-enzymatic browning, and lipid oxidation, can be prevented in a dried food with $\mathrm{a}_{\mathrm{w}}$ values near 0.3 (Ramaswamy and Marcotte, 2006).

Experimental results of the responses (drying time, moisture content, hardness, total soluble solids, $\mathbf{L}, \mathbf{a}, \mathbf{b})$ are listed in Table 2. Color is a perceptual phenomenon that depends on the observer and the conditions under which the color is observed (Sahin and Gulum Sumnu, 2006). Color is one of the more important quality parameters in dehydrated fruits and vegetables. Indeed, possible color changes would influence the organoleptic properties of dried orange peel samples and would limit their potential applications (Garau et al., 2007). The lightness (L), yellowness (b) and redness (a) were not affected significantly by the drying temperature and the air flow rate. $\mathbf{L}$ values were in the range of $36-50$, $\mathbf{b}$ values were in the range of $21-47$ and a values ranged from 9 to 16 (Table 2). Cortellino et al. (2011) applied osmodehydration to orange peels at atmospheric pressure in sucrose solution $(60 \mathrm{~g} / 100 \mathrm{~g}$ $\mathrm{w} / \mathrm{w}$ ) followed by air-drying at $80{ }^{\circ} \mathrm{C}$ and reported $\mathbf{L}$ data between $34-48$, $\mathbf{b}$ values in the range of $37-50$ and $\mathbf{a}$ values in the range of 16-30. The $\mathbf{L}$ and $\mathbf{b}$ results were in agreement with Cortellino et al. (2011) and Chafer et al. (2008), but a values were slightly lower compared to the data reported by Cortellino et al. (2011) and higher than the results found by Chafer et al. (2008).

The air flow rate also affected significantly the total soluble solids (TSS) of dried samples, but this response was not influenced significantly by the drying temperature. It is important to note that the coefficient of variation of TSS was higher than $30 \%$ in the ANOVA (data not shown). The samples dried at $30{ }^{\circ} \mathrm{C}$ also showed the higher ${ }^{\circ}$ Brix values (49 ${ }^{\circ}$ Brix) (Table 2). There was not a clear trend in this parameter because the harvest index of the raw material was not uniform and the vacuum impregnation (VI) process was influenced by the quality of the orange peel. Furthermore, the tissue microstructure plays an important role in the VI process. In this sense, the mass transfer properties during VI were affected by the thickness of the samples and the highly porous nature of the peel fraction of orange slices (Chafer et al., 2001).

Table 2: Experimental results for the drying process of orange peel samples.

\begin{tabular}{|c|c|c|c|c|c|c|c|}
\hline \multirow[t]{2}{*}{ Run order } & \multirow{2}{*}{$\begin{array}{l}\text { Drying time } \\
\text { (h) }\end{array}$} & \multirow{2}{*}{$\begin{array}{c}\text { Moisture content } \\
(\%)\end{array}$} & \multirow{2}{*}{$\begin{array}{l}\text { Hardness } \\
\text { (N) }\end{array}$} & \multirow{2}{*}{$\begin{array}{c}\text { TSS } \\
\left({ }^{\circ} \text { Brix }\right)\end{array}$} & \multicolumn{3}{|c|}{ Color } \\
\hline & & & & & $\mathbf{L}$ & $\mathbf{a}$ & b \\
\hline 1 & 7 & 6.41 & 92.9 & 16.9 & 48.8 & 15.5 & 33.6 \\
\hline 2 & 20 & 10.22 & 74.0 & 23.0 & 47.0 & 16.4 & 40.7 \\
\hline 3 & 24 & 8.35 & 74.9 & 21.1 & 49.8 & 16.2 & 37 \\
\hline 4 & 22 & 6.17 & 80.7 & 19.0 & 45.3 & 14.3 & 38.4 \\
\hline 5 & 18 & 6.82 & 85.1 & 32.8 & 35.4 & 16.3 & 26.4 \\
\hline 6 & 45 & 18.13 & 78.5 & 49.8 & 50.5 & 15.9 & 47.4 \\
\hline 7 & 23 & 8.44 & 76.0 & 28.0 & 49.0 & 14.3 & 34 \\
\hline 8 & 29 & 12.39 & 77.5 & 38.8 & 49.6 & 14.3 & 37.9 \\
\hline 9 & 23 & 10.44 & 72.4 & 32.3 & 43.0 & 16.4 & 36.5 \\
\hline 10 & 31 & 11.92 & 73.0 & 9.7 & 48.1 & 13.4 & 40.8 \\
\hline 11 & 33 & 11.93 & 78.0 & 10.9 & 41.0 & 11.2 & 30.7 \\
\hline 12 & 25 & 8.93 & 77.0 & 28.1 & 46.0 & 14.4 & 31.4 \\
\hline 13 & 23 & 10.70 & 77.0 & 28.1 & 36.0 & 9.4 & 21.4 \\
\hline
\end{tabular}


There were significant differences $(\mathrm{P}<0.05)$ between moisture content values of samples according to the drying temperature, but not the air flow rate (Figure 2(b)). The orange peel dried at $30^{\circ} \mathrm{C}$ reached moisture contents near $18 \mathrm{~g} / 100 \mathrm{~g}$, whereas the treatments of $55^{\circ} \mathrm{C}$ and $60{ }^{\circ} \mathrm{C}$ ranged between 6.1 and $6.8 \mathrm{~g} / 100 \mathrm{~g}$. One of the objectives of drying is to decrease the moisture content below $8 \mathrm{~g} / 100 \mathrm{~g}$ to prevent microbiological growth and the infestations of mites and insects in the product (Barbosa-Cánovas and Vega-Mercado, 1996).

Figure 2(c) shows the response surface for hardness $(\mathrm{N})$ of the dried samples. There were significant differences $(\mathrm{P}<0.05)$ between hardness according to the drying temperature, but not between air flow rates. The hardness of dried orange peel increased at higher drying temperatures. For instance, the hardness was $92.9 \mathrm{~N}$ of samples dried at $60{ }^{\circ} \mathrm{C}$, while the results at $45^{\circ} \mathrm{C}$ were in the range of $72-77 \mathrm{~N}$ (Table 2). In dried products, where cells are collapsed, the force of cellular bonds can be less relevant to product texture appreciation than the pectin content in the aqueous phase that affects its consistency. Mechanical properties of dehydrated products are closely related to the physical state, glassy or rubbery, and to the structure developed as a result of induced deformations (shrinkage/swelling) in cells and intercellular spaces and of ruptures of cellular bonds taking place throughout the drying process (Contreras et al., 2005). The hardness results of dried orange peel samples were in agreement with the data from air dried mango leathers (Azeredo et al., 2006), but higher than air-dried apple slices (Contreras et al., 2005) and oyster mushroom (Kotwaliwale et al., 2007).

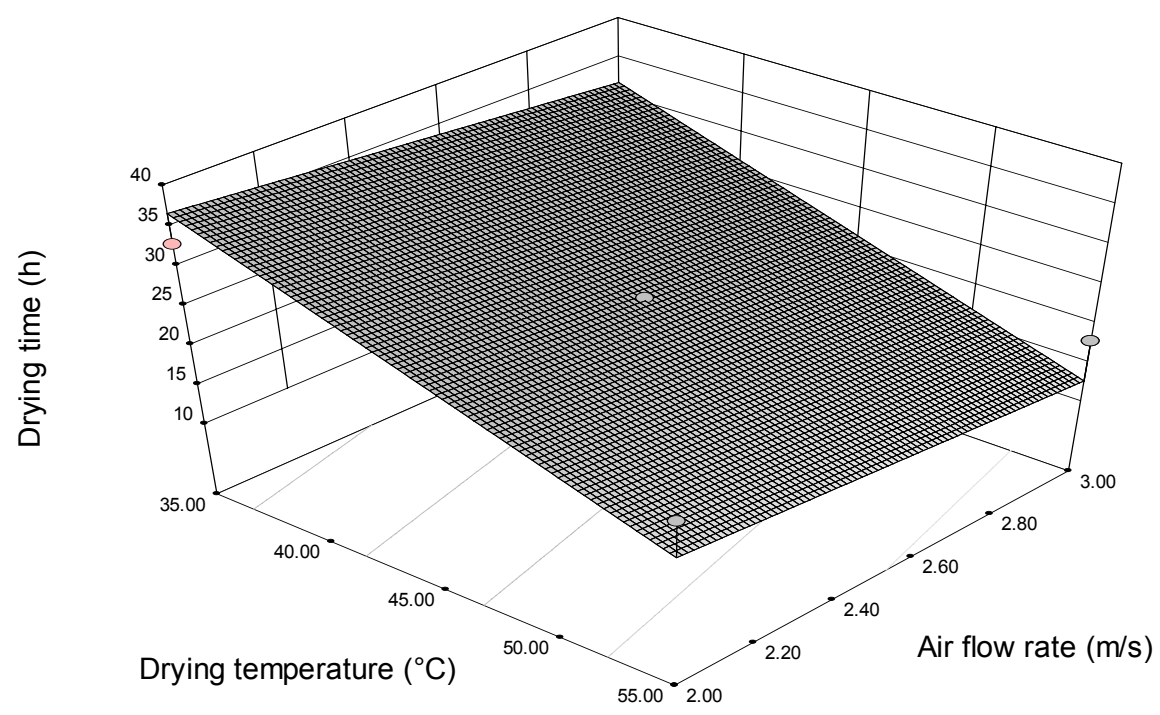

(a)

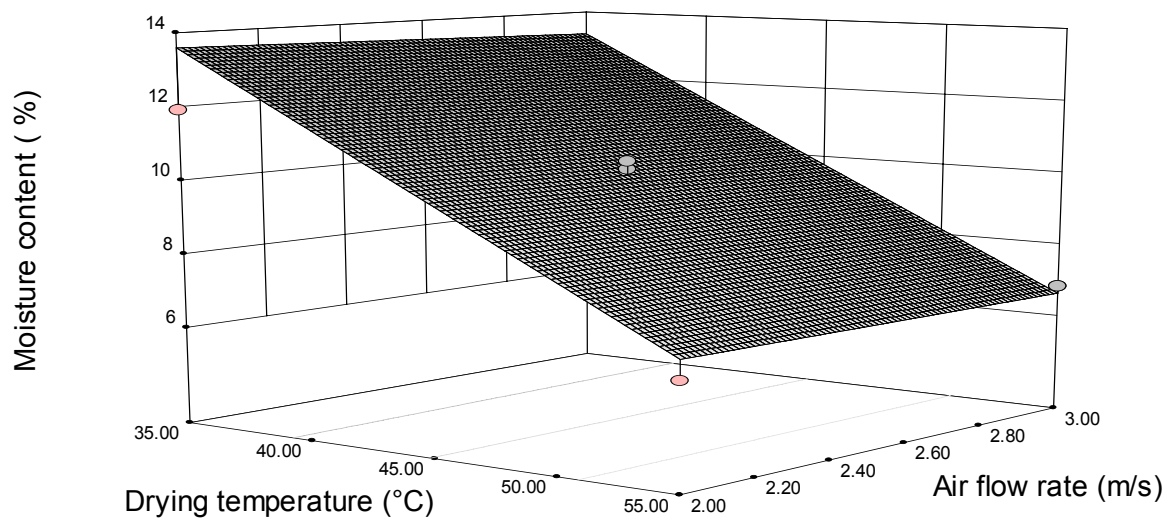

(b) 


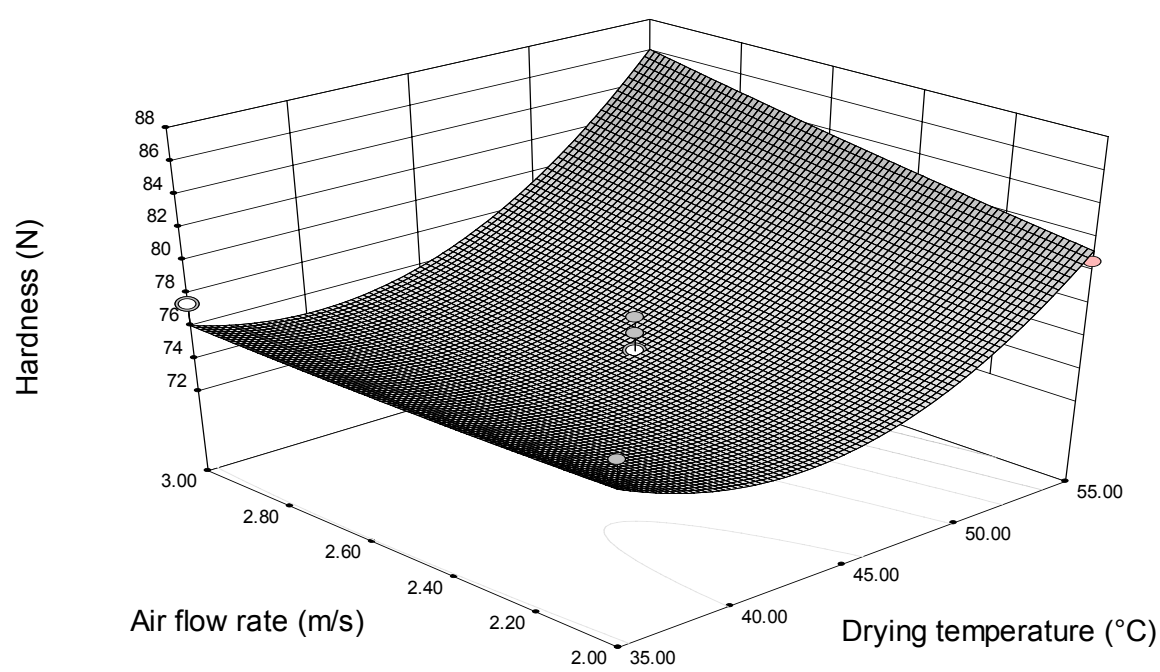

(c)

Figure 2: Response surface for drying time (a), moisture content (b) and hardness (c) of dried orange peel as a function of drying temperature and air flow rate.

The effect of drying variables on the responses and the independent variables expressed as a linear, quadratic and cross-product terms and ANOVA results of the models are shown in Table 3. A regression analysis was carried out to fit mathematical models according to the experimental data. Equations were developed for prediction of drying time $\left(\mathrm{Y}_{\text {time }}\right)$, moisture content $\left(\mathrm{Y}_{\text {moisture }}\right)$, and hardness ( $\left.\mathrm{Y}_{\text {hardness }}\right)$. The predictive models can be described in terms of the independent variables drying temperature $\left(\mathrm{X}_{1}\right)$, air flow rate $\left(\mathrm{X}_{2}\right)$ and their interactions. The cross-product and quadratic models were found to be statistically significant and the coefficients of determination $\left(\mathrm{R}^{2}\right)$ for the predictive models were 0.79 for $Y_{\text {moisture }}$ and 0.93 for $Y_{\text {hardness, }}$, respectively, suggesting that these models reasonably represent the observed values. Therefore, the response could be sufficiently explained by the model. The lack of fit test is a measure of the failure of a model to represent the data in the experimental domain at points not included in the regression. Although the $\mathrm{R}^{2}$ for the linear model of $\mathrm{Y}_{\text {time }}$ was 0.83 , this predictive model gave significant lack of fit and a high coefficient of variation (17\%), indicating that the experimental data were not satisfactorily explained (Madamba, 1997).

Optimum conditions for drying of orange peels in a tray drier were determined to obtain the minimum hardness, moisture content and drying time for $\mathrm{a}_{\mathrm{w}}$ values below 0.6 . This regression model was valid only in the selected experimental domain. In this study, the optimization was applied for the selected ranges of drying temperature and air flow rate of $35-55^{\circ} \mathrm{C}$ and $2-3 \mathrm{~m} / \mathrm{s}$, respectively. By applying the desirability function method, three solutions were obtained for the optimum criteria with a desirability value of 0.73 (Table 4). All were close to each other, as the drying temperatures varied between $52.3-52.6{ }^{\circ} \mathrm{C}$ and air flow rates was $2.0 \mathrm{~m} / \mathrm{s}$. In this circumstance, the solution which had the lowest hardness values for the highest product quality was selected (Erbay and Icier, 2009). The solutions were obtained for the optimum drying condition of $52.3{ }^{\circ} \mathrm{C}$ for drying temperature and $2.0 \mathrm{~m} / \mathrm{s}$ for the air flow rate. At this point, drying time, hardness and moisture content were calculated as $20 \mathrm{~h}, 78.4 \mathrm{~N}$ and $7.6 \%$, respectively.

Table 3: The ANOVA table showing equations for the independent drying variables of drying time, moisture content and hardness

\begin{tabular}{|c|c|c|c|c|c|c|c|}
\hline \multirow{2}{*}{ Response } & \multirow{2}{*}{ Equation } & \multicolumn{4}{|c|}{ Sum of squares } & \multirow{2}{*}{$\begin{array}{l}C V^{a} \\
(\%)\end{array}$} & \multirow{2}{*}{$\begin{array}{c}\text { R-square } \\
\left(\mathbf{R}^{2}\right)\end{array}$} \\
\hline & & Model & Residual & Pure error & Lack of fit & & \\
\hline $\begin{array}{l}\text { Drying time } \\
\text { (h) }\end{array}$ & $\mathrm{Y}_{\text {time }}=24.69-9.65 \mathrm{X}_{1}-2.32 \mathrm{X}_{2}$ & $279.4^{*}$ & 19.2 & 14 & $158.6^{*}$ & 17.7 & 0.83 \\
\hline $\begin{array}{l}\text { Moisture } \\
\text { content (\%) }\end{array}$ & $Y_{\text {moisture }}=10.07-3.4 X_{1}-0.085 X_{2}+0.048 X_{1} X_{2}$ & $98.4^{*}$ & 25.5 & 3.9 & $21.5^{\mathrm{ns}}$ & 16.7 & 0.79 \\
\hline $\begin{array}{l}\text { Hardness } \\
(\mathrm{N})\end{array}$ & $\begin{aligned} Y_{\text {hardness }} & =74.89+3.75 \mathrm{X}_{1}+11.6 \mathrm{X}_{2}+1.23 \mathrm{X}_{1} \mathrm{X}_{2} \\
& +4.93 \mathrm{X}_{1}^{2}+0.18 \mathrm{X}_{2}^{2}\end{aligned}$ & $343.3^{*}$ & 24.2 & 12.7 & $11.5^{\mathrm{ns}}$ & 2.38 & 0.93 \\
\hline
\end{tabular}

*Significant at $95 \%$ level; ${ }^{\text {ns }}$ Not significant; ${ }^{\text {a }}$ Coefficient of variation 
Table 4: Optimal conditions applying desirability function methodology

\begin{tabular}{|c|c|c|c|c|c|c|}
\hline Solution & $\begin{array}{c}\text { Drying temperature } \\
\mathbf{(} \mathbf{C})\end{array}$ & $\begin{array}{c}\text { Air flow rate } \\
(\mathbf{m} / \mathbf{s})\end{array}$ & $\begin{array}{c}\text { Drying time } \\
(\mathbf{h})\end{array}$ & $\begin{array}{c}\text { Hardness } \\
(\mathbf{N})\end{array}$ & $\begin{array}{c}\text { Moisture content } \\
(\mathbf{\%})\end{array}$ & Desirability \\
\hline 1 & 52.6 & 2.0 & 19.7 & 78.7 & 7.5 & 0.73 \\
2 & 52.5 & 2.0 & 19.8 & 78.6 & 7.5 & 0.73 \\
3 & 52.3 & 2.0 & 20.0 & 78.4 & 7.6 & 0.73 \\
\hline
\end{tabular}

\section{Sensory Evaluation}

A consumer test of dried orange peels from the optimum drying process was applied to assess the overall product acceptability. Acceptance methods measure the degree to which a product is liked/ disliked and give interval or ratio data (Hein et al., 2008). The results of the sensory test of dried samples from the optimum drying process coated with chocolate are shown in Figure 3. The percentages of consumers were $32 \%$ for both $20-30$ year-old young adults and 40-50-year-old adults, $20 \%$ for $30-40$-year-old adults and $17 \%$ for $50-60$ year-old adults. The dried samples were accepted by $63 \%$ of the consumers and rejected by $18 \%$ of the subjects. The high rate of rejection of this product was focused in young adults. This result suggested that young adults in the region where the test was applied (Antioquia, Colombia) consume few products with bitter notes, such as bitter coffee or dark chocolate, and have a greater preference for the sweet and salty tastes. On the other hand, $80 \%$ of consumers aged more than 30 years old accepted the dried orange peels coated with chocolate, especially in elderly adults, where the acceptance was close to $100 \%$. The sensory data highlighted the target segment of this product, which could be middle-aged and elderly consumers because they have a greater preference for the bitter notes in a food.

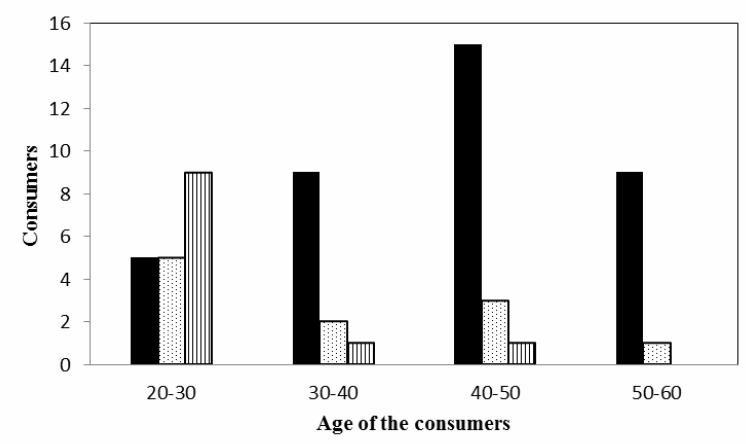

Figure 3: Sensory responses of the affective test for dried orange peel from the optimum drying process coated with chocolate according to the age of the consumers. Like (a). neither like nor dislike (f). dislike (\|)

\section{CONCLUSION}

The dried orange peel responses were significantly dependent on drying temperature. Changing the process conditions significantly affected the properties of the samples. The orange peel dried at $30{ }^{\circ} \mathrm{C}$ had the highest moisture contents $(18 \mathrm{~g} / 100 \mathrm{~g})$, TSS values ( $49^{\circ}$ Brix) and drying time $(45 \mathrm{~h})$. The optimum conditions for drying of orange peels were determined to obtain minimum hardness, moisture content and drying time for $\mathrm{a}_{\mathrm{w}}$ values below 0.6 . The optimum condition was found to be a dying temperature of $52.3{ }^{\circ} \mathrm{C}$ and air flow rate of $2.0 \mathrm{~m} / \mathrm{s}$ in order to obtain a drying time of $20 \mathrm{~h}$, hardness of $78.4 \mathrm{~N}$ and moisture content of $7.6 \mathrm{~g} / 100 \mathrm{~g}$. Dried orange peel from the optimum drying process coated with chocolate was widely accepted by consumers aged more than 30 years old. However, the study suggests that processing history and quality of orange samples should be taken into consideration in order to obtain better dried products.

\section{ACKNOWLEDGEMENTS}

The research grant from COLCIENCIAS is greatly appreciated by K. Manjarres-Pinzon.

\section{REFERENCES}

AOAC, Standard Methods 20.013. Official Methods of Analysis. Association of Official Analytical Chemist. Washington DC, $13^{\text {th }}$ Ed. (1980).

Atarés, L., Chiralt, A., González-Martínez, C., Effect of the impregnated solute on air drying and rehydration of apple slices. Journal of Food Engineering, 91, 305-310 (2009).

Azeredo, H., Brito, E. S., Moreira, G., Farías, V. L., Bruno, L. M., Effect of drying and storage time on the physico-chemical properties of mango leathers. International Journal of Food Science and Technology, 41, 635-638 (2006).

Barbosa-Cánovas, G. V., Vega-Mercado, H., Dehydration of Foods. Chapman \& Hall, New York, NY, 265-288 (1996).

Barajas, J., Cortes-Rodriguez, M., Rodriguez-Sandoval, 
E., Effect of temperature on the drying process of bee pollen from two zones of Colombia. Journal of Food Process Engineering, 35, 134-148 (2012).

Brião, V. B., Granhen Tavares, C. R., Effluent generation by the dairy industry: Preventive attitudes and opportunities. Brazilian Journal of Chemical Engineering, 24, (4), 487-497 (2007).

Chafer, M., Gonzalez-Martinez, C., Ortola, M. D., Chiralt, A., Fito, P., Kinetics of osmotic dehydration in orange and mandarin peels. Journal of Food Process Engineering, 24, (4), 273-289 (2001).

Chafer, M., González-Martínez, C., Chiralt, A., Fito, P., Microstructure and vacuum impregnation response of citrus peels. Food Research International, 36, 35-41 (2003).

Chafer, M., Perez, S., Vargas, M., Chiralt, A., Stability and quality of minimally processed orange slices. Journal of Food Processing and Preservation, 32, 319-334 (2008).

Claussen, I. C., Strommen, I., Egelandsdal, B., Straetkvern, K. O., Effects of drying methods on functionality of a native potato protein concentrate. Drying Technology, 25, (6), 1091-1098 (2007).

Contreras, C., Martín, M. E., Martínez-Navarrete, N., Chiralt, A., Effect of vacuum impregnation and microwave application on structural changes which occurred during air-drying of apple. LWT Food Science and Technology, 38, 471-477 (2005).

Cortellino, G., Gobbi, S., Torreggiani, D., New prospects for high quality ingredients obtained from citrus fruit peel. Procedia Food Science, 1, 1848-1853 (2011).

El-Aouar, A. A., Azoubel, P. M., Barbosa, J. L., Murr, F. E. X., Influence of the osmotic agent on the osmotic dehydration of papaya (Carica papaya L.). Journal of Food Engineering, 75, 267274 (2006).

Erbay, Z., Icier, F., Optimization of hot air drying of olive leaves using response surface methodology. Journal of Food Engineering, 91, 533-541(2009).

Femenia, A., Sastre-Serrano, G., Simal, S., Garau, M. C., Eim, V. S., Rosselló, C., Effects of airdrying temperature on the cell walls of kiwifruit processed at different stages of ripening. LWT Food Science and Technology, 42, 106-112 (2009).

Garcia-Perez, J. V., Cárcel, J. A., Riera, E., Mulet, A., Influence of the applied acoustic energy on the drying of carrots and lemon peel. Drying Technology, 27, 281-287 (2009).

Garcia-Perez, J. V., Ortuño, C., Puig, A., Carcel, J. A., Perez-Munuera, I., Enhancement of water transport and microstructural changes induced by high-intensity ultrasound application on orange peel drying. Food and Bioprocess Technology, 5, (6), 2256-2265 (2012).

Garau, M. C., Simal, S., Rosselló, C., Femenia. A., Effect of air-drying temperature on physicochemical properties of dietary fibre and antioxidant capacity of orange (Citrus aurantium v. Canoneta) by-products. Food Chemistry, 104, 1014-1024 (2007).

Geankoplis, C. J., Transport Processes and Unit Operations. Prentice Hall International, Englewood Cliffs, NJ., 579-634 (1993).

Hein, K. A., Jaeger, S. R., Carr, T., Delahunty, C. M., Comparison of five common acceptance and preference methods. Food Quality and Preference, 19, 651-661 (2008).

Kratchanova, M., Pavlova, E., Panchev, I., The effect of microwave heating of fresh orange peels on the fruit tissue and quality of extracted pectin. Carbohydrate Polymers, 56, 181-185 (2004).

Kotwaliwale, N., Bakane, P., Verma, A., Changes in textural and optical properties of oyster mushroom during hot air drying. Journal of Food Engineering, 78, (4), 1207-1211 (2007).

Laufenberg, G., Kunz, B., Nystroem, M., Transformation of vegetable waste into value added products: (A) the upgrading concept; (B) practical implementations. Bioresource Technology, 87, 167-198 (2003).

Madamba, P. S., Optimization of the drying process: An application to the drying of garlic. Drying Technology, 15, (1), 117-136 (1997).

Meilgaard, M., Civille, G. V., Carr, B. T., Sensory Evaluation Techniques. CRC Press LLC, Boca Raton, Fl. 3th Ed., 231-263 (1999).

Miller, W. M., Braddock, R. J., Microwave drying of citrus peel. Proceedings of the Florida State Horticultural Society, 95, 204-207 (1982).

Myers, R. H., Montgomery, D. C., Response Surface Methodology: Process and Product Optimization Using designed Experiments. John Wiley and Sons, Inc., New York, 2nd. Ed., 328-335 (2002).

Ortuño, C., Pérez-Munuera, I., Puig, A., Riera, E., García-Perez, J.V., Influence of power ultrasound application on mass transport and microstructure of orange peel during hot air drying. Physics Procedia, 3, 153-159 (2010).

Ramaswamy, H., Marcotte, M., Food Processing Principles and Applications. CRC Press, Boca Raton, Fl, 233-277 (2006).

Ruiz-Díaz, G., Martínez-Monzó, J., Fito, P., Chiralt, A., Modelling of dehydration-rehydration of orange slices in combined microwave/air drying. Innovative 
Food Science and Emerging Technologies, 4, 203209 (2003).

Sahin, S., Gulum Sumnu, S., Physical Properties of Foods. Springer Verlag, New York, NY, 162-170 (2006).

Senevirathne, M., Jeon, Y. J., Ha, J. H., Kim, S. H., Effective drying of citrus by-product by high speed drying: A novel drying technique and their antioxidant activity. Journal of Food Engineering, 92, 157-163 (2009).

Shi, Q. L., Xue, C. H., Zhao, Y., Li, Z. J., Wang, X. Y., Luan, D. L., Optimization of processing parameters of horse mackerel (Trachurus japonicus) dried in a heat pump dehumidifier using response surface methodology. Journal of Food Engineering, 87, (1), 74-81 (2008).

Slama, R. B., Combarnous, M., Study of orange peels dryings kinetics and development of a solar dryer by forced convection. Solar Energy, 85, 570-578 (2011).

Toledo, R. T., Fundamentals of Food Process Engineering. Springer Verlag, New York, NY, 431-473 (2007).

Wuttipalakorn, P., Srichumpuang, W., Chiewchan, N., Effects of pretreatment and drying on composition and bitterness of high-dietary-fiber powder from lime residues. Drying Technology, 27, 133-142 (2009). 